\title{
PARTICULARITIES OF CSR PROGRAMS DURING THE COVID-19 PANDEMIC
}

\author{
Simona Aurelia BODOG ${ }^{1}$, Nicoleta Alina ANDREESCU ${ }^{2}$ \\ ${ }^{1}$ Department of Management-Marketing, Faculty of Ecomonic Sciences, University \\ of Oradea, Oradea, Romania \\ ${ }^{2}$ Department Textiles-Leatherwork and Industrial Management, Faculty of Energy \\ Engineering and Industrial Management, University of Oradea, Oradea, Romania \\ simonabodog@gmail.com \\ nandreescu@uoradea.ro
}

\begin{abstract}
In 2020, the COVID-19 pandemic transformed the lives of all people. The most affected sectors were the medical, educational and disadvantaged communities. The purpose of this paper is to analyze the way in which Romanian companies have adapted their CSR programs to the new conditions of the social and economic environment. The health crisis of 2020 highlighted the deficiencies in the health system and stressed the need for collaboration between the state and the private sector to overcome it. The increase in the demand for protective equipment, medical equipment has accelerated the collaboration between private companies and hospitals, which intervene by donating the necessary materials to those in the front line. The educational system was severely affected: the school had to run online, but many students and teachers did not have the necessary equipment and knowledge and in these conditions the risk of dropping out of school was very high, especially in disadvantaged communities. The CSR programs of Romanian companies also focused to this field, donating equipment: laptops, tablets or free internet connection for schools and for students with limited financial resources. The priorities of the CSR programs were directed in 2020, especially towards these fields in response to the needs of society.
\end{abstract}

Keywords: COVID-19, CSR, health services, education.

JEL Classification: 100, 118, 124, M14.

\section{Introduction}

With the increasing impact of the COVID-19 pandemic on society, the business environment, companies need to develop corporate social responsibility programs so that the benefits are mutual, a situation that involves adapting to the global pandemic.

The effect of the COVID-19 pandemic accentuated the inequalities in the society: unemployment, social crises (education, health), economic problems even the developed world and determined the increase of the vulnerabilities of the society in front of the appeared problems. Human health, income, shelter and other goals of life are now caused by many more risks and uncertainties arising from COVID-19 attacks. The only lever that can link business interests to social interests is community trust, and empathy is an important indicator for building trust (Boadi et 
al., 2019). Thus, in this critical period, the moral duty of companies is to support society.

In all countries there have been and still are concerns for studying the possibilities of adapting social responsibility programs in times of crisis and identifying the effects of this adaptation on society.

\section{Literature review}

A group of Spanish researchers (Raimo, N., Rella, A., Vitolla, F., Sánchez-Vicente, M-I., García-Sánchez, M-I., 2021) examines how Spanish companies have supported society and vulnerable individuals through partnerships with non-governmental organizations (NGOs). The results of this study indicate that these partnerships are mainly aimed at providing food, health, social and technological support to society and vulnerable individuals. The authors (Raimo, N., Rella, A., Vitolla, F., SánchezVicente, M-I., García-Sánchez, M-I., 2021) report that this is the first study that examines the support provided by companies to society during the COVID-19 pandemic in the European context.

Another study (Mahmud, Ding, Hasan, 2021) explores business responses to the COVID-19 pandemic to support employees, customers, communities, and society as a whole through CSR initiatives. Results of this research report that companies show respect to their employees and focus on stewardship relations between corporations and customers and communities during the COVID-19 pandemic.

Hongwei He and Lloyd Harris (2020), (Hongwei and Lloyd, 2020), examine how the Covid-19 pandemic may influence CSR developments and highlights how consumer decision-making will be affected by the pandemic.

Another study by Italian researchers (Patuelli et al. 2021) provides information on the major problems and challenges facing companies in the Covid-19 pandemic and their concerns about corporate social responsibility (CSR) following an investigation into Twitter discussions of major Italian companies in the first months of the pandemic. The results of the study highlight the contribution of online social networks and the role of online social networks in understanding the problems, challenges and responsibilities of companies, with common narratives that flow naturally from the data.

In Romania, too, several studies have been conducted that analyze how the pandemic affects society and the economy and assess the impact of the effects of the COVID-19 pandemic on society. The purpose of these studies is related to the need to change the attitude of citizens and assume the social responsibility of companies (Zamfir and Zamfir, 2020).

\section{CSR programs of companies during the COVID-19 Pandemic}

The COVID-19 pandemic has, in addition to its effects on the population's health, multiple social implications: social relations have undergone significant changes (social distancing), the way people relate to themselves and other members of society, lifestyle changes through by restricting access to public space, online education, and encouraging companies to promote homework for their employees. 
The economic impact was obvious: many companies restricted their activity, employees went on unpaid leave or unemployment and others lost their jobs.

In this context, the CSR programs of the companies have been adapted to the new needs of the society and the communities in which they operate.

The purpose of this paper is to analyze the way in which Romanian companies have adapted their CSR programs to the new conditions of the social and economic environment and in these conditions we have analyzed the CSR programs of some companies in Romania that were involved in the crisis caused by Covid -19 .

The criteria by which these companies were chosen are:

-the amount of money invested in the program,

-visibility, the way in which stakeholders were informed about the adaptation of the CSR program to the new conditions imposed by the pandemic,

-the speed with which the CSR program adapted to the new realities, -the domains in which they were active.

Table 1: Representative CSR activities by Romanian companies during the COVID-19 Pandemic

\begin{tabular}{|c|c|c|c|}
\hline Activity sector & Company & Ways to get involved & $\begin{array}{l}\text { The } \\
\text { amount } \\
\text { invested }\end{array}$ \\
\hline Financial & $\begin{array}{l}\text { Banca } \\
\text { Transilvania }\end{array}$ & $\begin{array}{l}\text { Money and equipment for } \\
\text { hospitals and for } 30 \\
\text { communities. } \\
\text { Accelerate the launch of online } \\
\text { banking solutions to allow } \\
\text { permanent access to products } \\
\text { and services. } \\
\text { Measures to support } \\
\text { customers with loans affected } \\
\text { by the pandemic } \\
\text { Continuing the business by } \\
\text { continuing all operations. }\end{array}$ & $\begin{array}{l}2.000 .000 . \\
\text { Euro }\end{array}$ \\
\hline Financial & $\begin{array}{l}\text { BRD } \\
\text { Groupe } \\
\text { Société } \\
\text { Générale }\end{array}$ & $\begin{array}{l}\text { Donation for the medical } \\
\text { sector }\end{array}$ & $\begin{array}{l}1.700 .000 \\
\text { Lei }\end{array}$ \\
\hline Financial & CEC Bank & $\begin{array}{l}\text { Sponsorships to nine frontline } \\
\text { hospitals in the fight against } \\
\text { COVID-19 }\end{array}$ & $\begin{array}{l}1.000 .000 \\
\text { Lei }\end{array}$ \\
\hline Financial & $\begin{array}{l}\text { OTP Bank } \\
\text { România }\end{array}$ & $\begin{array}{l}\text { Donation for the purchase of } \\
\text { equipment and materials } \\
\text { necessary for medical staff. }\end{array}$ & $\begin{array}{l}500.000 \\
\text { Lei }\end{array}$ \\
\hline Telecomunications & RCS RDS & $\begin{array}{l}\text { Donations of } r \text { medical } \\
\text { equipment for } \\
\text { departments. } \\
\text { Donations of medical } \\
\text { equipment and connectivity } \\
\text { services for children from }\end{array}$ & $\begin{array}{l}\text { No info } \\
\text { provided }\end{array}$ \\
\hline
\end{tabular}




\begin{tabular}{|c|c|c|c|}
\hline & & $\begin{array}{l}\text { disadvantaged areas or } \\
\text { isolated communities. }\end{array}$ & \\
\hline Telecomunications & Orange & $\begin{array}{l}\text { Health projects: eight public } \\
\text { hospitals were equipped with } \\
\text { artificial ventilation devices and } \\
\text { protection equipment. } \\
\text { Digital education } \\
\text { Social inclusion and } \\
\text { community support projects. }\end{array}$ & $\begin{array}{l}400.000 \\
\text { Euro } \\
\\
550.000 \\
\text { Euro } \\
380.000 \\
\text { Euro }\end{array}$ \\
\hline Retail & LIDL & $\begin{array}{l}50.000 \text { collection kits for nasal } \\
\text { and pharyngeal exudate, } \\
\text { needed to perform molecular } \\
\text { diagnostic tests in the } \\
\text { beginning of the pandemic. } \\
\text { Donations for the SMURD } \\
\text { Foundation and DSU to } \\
\text { purchase the first mobile } \\
\text { therapy unit, intended for the } \\
\text { treatment of patients with } \\
\text { SARS-CoV } 2 \text { infected and in } \\
\text { critical condition. } \\
20 \text { oxygen concentrators for } \\
\text { the Botosani Emergency } \\
\text { Hospital. Donations in the } \\
\text { "Românii Împreună pentru } \\
\text { dotarea sectiilor de Terapie } \\
\text { Intensivă" Campaign. }\end{array}$ & $\begin{array}{l}1.208 .000 \\
\text { Lei }\end{array}$ \\
\hline Beverage & $\begin{array}{l}\text { Coca Cola } \\
\text { România }\end{array}$ & $\begin{array}{l}\text { Donations to the Red Cross for } \\
\text { the purchase of necessary } \\
\text { medical equipment. } \\
\text { Drinks covering one month's } \\
\text { supply of Covid-19 infectious } \\
\text { disease hospitals and } \\
\text { quarantine centers in the } \\
\text { country. }\end{array}$ & $\begin{array}{l}100.000 \\
\text { Euro } \\
100.000 \\
\text { Euro }\end{array}$ \\
\hline Energy & $\begin{array}{l}\text { OMV } \\
\text { Petrom }\end{array}$ & $\begin{array}{l}\text { Donation for the purchase of } \\
\text { COVID19 rapid diagnostic test } \\
\text { equipment. }\end{array}$ & $\begin{array}{l}1.000 .000 \\
\text { Euro }\end{array}$ \\
\hline Energy & $\begin{array}{l}\text { ENGIE } \\
\text { România }\end{array}$ & $\begin{array}{l}\text { Purchase of medical } \\
\text { equipment for the endowment } \\
\text { of three medical units in } \\
\text { Bucharest and Brassov. } \\
\text { Financial contribution directed } \\
\text { to several NGOs. }\end{array}$ & $\begin{array}{l}110.000 \\
\text { Euro }\end{array}$ \\
\hline Pharmaceutical & Sanofi & $\begin{array}{l}\text { Donations of drugs used in the } \\
\text { treatment of patients infected } \\
\text { with the SARS-CoV-2 virus }\end{array}$ & $\begin{array}{l}\text { No info } \\
\text { provided }\end{array}$ \\
\hline
\end{tabular}




\begin{tabular}{|l|l|l|l|}
\hline & & $\begin{array}{l}\text { (Hidroxiclorochine) have been } \\
\text { donated to the Ministry of } \\
\text { Health, }\end{array}$ & \\
\hline Insurance & Allianz- & $\begin{array}{l}\text { Equipping with five ATI } \\
\text { devices the modular hospital in } \\
\text { the yard of Elias Hospital in } \\
\text { Bucharest for the treatment of } \\
\text { serious cases of COVID-19. }\end{array}$ & \\
\hline
\end{tabular}

Source: made by the authors based on data collected from the companies' sites

By analyzing the way in which companies have adapted their CSR programs to the new social realities, we can see some common points of them:

- all the analyzed companies directed their CSR campaigns to hospitals, schools and disadvantaged people,

- the donation was the main CSR tactic that the companies adopted,

- the companies collaborated with each other to support projects and NGOs that carried out their activity in these fields (eg. the campaign Dăruieste viață!),

- the companies analyzed and published through the media the actions of CSR in order to become a good example for other companies but also to be close to people to prove to them that they are together in this crisis.

\section{Conclusions}

The health crisis has affected the lives of all people but also the way companies do business. Both people and companies have had to adapt to new social and economic realities in a very short time.

Under these conditions, the companies turned their attention to the employees, understanding that only by protecting them and the community can they continue to carry out their activity.

CSR programs have been adapted to new realities and the priority has been a donation to hospitals to provide protective materials and medical equipment; most CSR actions have been directed in this direction.

Companies whose field of activity is telecommunications, in addition to donations to hospitals, have also targeted schools and students. Through their programs, the companies have equipped students with reduced possibilities, with laptops or tablets and with an internet connection in order to be able to participate in online classes and to continue their education.

We can see that the CSR programs of the companies have seen an increase in the pandemic, although they have been directed in only two or three areas of interest: health, education and the environment, in some cases.

As a result, companies have moved closer to the community and have been perceived as a "good citizen", an integral part of the community, responding to its needs in crisis situations and adapting its CSR strategy to the needs of stakeholders.

We believe that the CSR policy of companies has become stronger and more visible in the new economic and social conditions. 


\section{References}

1. Allianz-Tiriac Asigurari sustine lupta impotriva noului coronavirus si doneaza 80.000 de euro, available at https://www.allianztiriac.ro/ro_RO/comunicate-depresa/comunicate-de-presa/allianz-tiriac-doneaza-pentru-tratarea-pacientilor-in-starecritica.html, accessed June 2021

2. Banca Transilvania si eMAG continua implicarea in lupta cu COVID-19 si doneaza inca 2 milioane de lei (2020, 29 aprilie, INFO-COVID), available at https://www.bancatransilvania.ro/bt-social-media-newsroom/stiri/banca-transilvania-siemag-continua-implicarea-in-lupta-cu-covid-19, accessed June 2021

3. BRD donează 2 milioane de lei pentru a susține sectorul medical și ecosistemul cultural independent (2020, 19 martie), available at https://www.brd.ro/brd-doneaza-2milioane-de-lei-pentru-sustine-sectorul-medical-si-ecosistemul-cultural-independent, accessed June 2021

4. Boadi, E. A., He, Z., Bosompem, J., Say, J., Boadi, E. K. (2019), Let the talk count: Attributes of stakeholder engagement, trust, perceive environmental protection and CSR, SAGE Open, 9(1), 1-15, https://doi.org/10.1177/2158244019825920

5. CEC Bank, available at https://www.cec.ro/noutati, accessed September 2021

6. Coca-Cola România, Doar împreună, de la distanță, putem depăși mai ușor acest impas! (2020, 26 martie), available at https://www.coca- cola.ro/desprenoi/actiunile-noastre/initiativele-coca-cola-coronavirus/sistemul-coca-cola-donatie-covid,

accessed September 2021

7. Donație de la SANOFI de peste un milion de doze de Hidroxiclorochinină, un medicament vital în lupta împotriva pandemiei COVID-19 (2020, 03 aprilie), available at http://www.ms.ro/2020/04/03/donatie-de-la-sanofi-de-peste-un-milion-dedoze-de-hidroxiclorochinina-un-medicamente-vital-in-lupta-impotriva-pandemiei-covid-

19/, accessed August 2021

8. ENGIE Romania continuă sprijinul în lupta împotriva COVID-19 și donează 110.000 euro către Dăruiește Viată pentru achiziția de echipamente medicale (2021, 19 aprilie), available at https://www.engie.ro/engie-romania-continua-sprijinulin-lupta-impotriva-covid-19-si-doneaza-110-000-euro-catre-daruieste-viata-pentru-

achizitia-de-echipamente-medicale/, accessed September 2021

9. Hongwei, H., Lloyd, H., (2020), The impact of Covid-19 pandemic on corporate social responsibility and marketing philosophy, Elsevier Public Health Emergency Collection, doi: 10.1016/j.jbusres.2020.05.030

10. Lidl Romania, available at https://corporate.lidl.ro/, accessed June 2021

11. Mahmud, A., Donghong, D., Hasan, MM., Corporate Social Responsibility: Business Responses to Coronavirus (COVID-19) Pandemic (2021), SAGE Open, https://www.mottmac.com/views/adapting-corporate-social-responsibility-to-covid-19, https://doi.org/10.1177/2158244020988710

12. Patuelli A, Caldarelli G, Lattanzi N, Saracco F (2021), Firms' challenges and social responsibilities during Covid-19: A Twitter analysis, PLoS ONE 16(7): e0254748. https://doi.org/10.1371/journal.pone.0254748

13. Panagiotopoulos, I. Novel CSR \& novel coronavirus: Corporate Social Responsibility inside the frame of coronavirus pandemic in Greece. Int J Corporate Soc Responsibility 6, 10 (2021). https://doi.org/10.1186/s40991-021-00065-7

14. Prima tranșă de echipamente ATI donate de grupul DIGI a ajuns la spitalele din țară (2020, 25 mai), available at https://www.digi.ro/anunturi/prima-transa-de- 
echipamente-ati-donate-de-grupul-digi-a-ajuns-la-spitalele-din-tara-18217,

accessed September 2021

15. Orange, Responsabilitate socială, Comunicate de presă, preluat de pe https://www.orange.ro/newsroom/comunicate-de-presa/responsabilitate-sociala-3

accessed June 2021

16. OMV Petrom, Rapoarte de sustenabilitate, available at https://www.omvpetrom.com/ro/sustenabilitate/rapoarte-de-sustenabilitate, accesesed September 2021

17. OTP Bank, available at https://www.otpbank.ro/ro, accessed September 2021

18. Raimo, N., Rella, A., Vitolla, F., Sánchez-Vicente, M-I., García-Sánchez, M-I. (2021), Corporate Social Responsibility in the COVID-19 Pandemic Period: A Traditional Way to Address New Social Issues, Sustainability, 13(12), 6561; https://doi.org/10.3390/su13126561

19. Zamfir C. and Zamfir E. (2020), Calitatea vietii in timpul pandemiei: probleme si politici de raspuns, Raport social al ICCV 2020, ICCV, Academia Romana, available at https://acad.ro/SARS-CoV-2/doc/d01-CalitateaVietii.pdf 